\title{
Kinesics and Symbol Language: Sociolinguistics Study Model in Multilingual Approach Context
}

\author{
Udjang Pairin M. Basir \\ Lecturer \\ Surabaya State University \\ Indonesia \\ Amirotul Ro'ifah \\ Lecturer \\ STIE Dewantara Jombang \\ Indonesia
}

\begin{abstract}
:
In multilingual societies, the language system as a communication tool is so complex. In the broader context the communication process in society is not only in the form of verbal but also nonverbal which is more abstract and symbolic value. Nonverbal languages deal with body cues, such as hand gestures, facial expressions, smiles, hand waves, and others are called kinesics. However, there are also nonverbal languages in other forms, namely symbols, colors and sounds. Deals with symbols, such as eagle (state symbol), star (divinity), symbol of rank (police and army); red (bravery), white (holy), black (sad, mourning), blue (love); kentongan (sound of instrument hit as a sign of time and danger), syringe sound (ask for road), whistle sound (warning or morse language), etc. Which the meaning requires a cultural understanding.

Kinesics itself includes a paralinguistic study which meaning involves a relatively loose aspect of culture, so it is often cause misinterpretation, but not so in symbolic language. The symbol system of meaning is more certain. As part of cultural element, the understanding process of symbols language is more directed references and relatively inconvenience to the whole community supporters.
\end{abstract}

Keywords: Kinesik, symbol language, sociolinguistic, multilingual approach

\section{Preface}

For several centuries, language understanding has always been focused on anything that is verbal. Speaking is the process of communication by using a series of words arranged in such a way that the form of linguistic clusters that is logical and meaningful. In every language appearance should always consider the existence of its main elements (subject and predicate). Otherwise, any form of communication would be regarded as an aberration.

Due to the increasing acceptability of language facts as social facts, the context-oriented language model (sociolinguistic) is recognized for its existence (Weinreich, 1953; Fishman 1972; Labov 1972; Hymes 1974). And the essence of language is the acceptability of information by those concerned. The presence of participants directly makes linguistic aspects that have been mutually understood need not be disclosed. Therefore, spoken language often appears as incomplete linguistic fragments, even if meaningfully (content of communication) is not so.

In multilingual societies, the language system as a communication tool is so complex. Beside the existence of mixing language phenomenon also causes the social contact system more volatile and varied. In the broader context, communication process in society is not only in verbal form, but also found many non-verbal communication models, in the form of hand movements, facial expressions (mimic), smile, glances, and other body cues (kinesics). Nonverbal communication acts are functional, as they are used to clarify, confirm, and complete the verbal communication functions. Both are needed to complete each other in order to achieve the effectiveness of communication (Effendy, 2004, Suandi, 2016). 


\section{Verbal and Nonverbal Language}

Verbal language is a communication model using words. The form can be either written or spoken. The written language always puts the functional elements of the language as its main requirement. It is important to avoid ambiguity understanding (Arifin, 1987: 17-21; Moeliono, 1990: 66). If written language is one-way, the spoken language is the opposite, two-way or even more. Thus, spoken language is more concerned with the aspects of group or collective communication (Pateda, 1987: 34; Hudson, 1988: 12).

In addition to verbal language, in society also found nonverbal language. Nonverbal language as a medium of communication in society that is more related to cultural aspects. As it is known that the meaning of communication is also determined by the high-low of sound, the loud and soft voice, color of sound or timbre and even body movement (Chaika, 1982: 54; Kartomihardjo, 1988: 73).

Someone who speaks with a loud and high tone, even if in formal linguistic has good meaning, praises, but can make the recipient offended or frightened. For example, the phrase "Gratitude!" to someone who get calamity, certainly it does not mean praising felt by the recipient, but accepted as an insult. Unlike the case when the word is said with a low and soft tone, certainly it makes happy the listener. Similarly, those who speak in a "hoarse" voice can be interpreted as being ill or asking for help, and so on.

In other situations, the meaning of language can also be obtained through body movements, facial expressions, and even far-reaching speech positions. The variety of communication expressed through such body movements is called. Kinesics language as one type of variety in a communication is a paralinguistic system that giving the meaning involves understanding the social context and cultural aspects of society. In addition to kinesics, in the community found also a model of communication using a sign system, such as a war code (voice or light), a sign of rank and attributes in the army, traffic signs, scouting activities, musical instrument and cakrik (form) puppets, kentongan and bendhe sound (small gong), and so forth. All that can be interpreted by tracing the philosophical and cultural aspects that lie behind them. The means are referred to as symbols (symbols) of language. It illustrates that there is a link between language and social reality. Language forms the reality, which SaphirWhorf calls Linguistic Relativity theory (Rejeki, 2010: 51).

\section{Kinesics Language}

In communication, someone sometimes does not express it with words, but only do it with body cues. The shape varies, for example with a nod, a smile, a shake of the head, glances and eyebrows, hand movements and fingers, shoulder movements, hip wobble, or the other. All aspects of the body cues prevailing in society are studied as part of a human social communication system called kinesics (Chaika 1982: 54; Kartomihardjo 1988: 73).

Kinesics itself is a paralinguistic system that usually accompanies verbal communication process. Paralinguistic studies are still very few and have not gained the same systematic way of view (Kridalaksana, 1983: 120). However, it is agreed that the aspect of his understanding is closely related to the cultural values and style of a person who is not uncommon as a determinant of the real meaning of language. Therefore, it is often cause misunderstanding to a kinesics because it is based only on the general feeling and analogy that occurs in a community.

It should be noted that the meaning of kinesics cues sometimes differs from one culture to another. Therefore, the limitation of understanding to culture can lead to misinterpretation of certain kinesics elements which Hall (1959) calls the silent language. Although every culture has a tendency to have its own kinesics system, there are models of universal kinesics form.

\subsection{Instinct and Learning}

In general there are two groups of kinesics found in human beings. There is a kinesic model derived naturally as an innate instinct, and some are obtained through learning from its cultural environment (Chaika in Kartomihardjo, 1988: 74). The biological character of the baby, when crying can be interpreted because of hunger, thirst, pain, or uncomfortable because of urine. Similarly, if it appears a lot of motion, babbling, and laughing as a hint that the baby is healthy and happy. All the kinesic elements happen by themselves without having to be learned by someone first and all are naturally acquired as a congenital innate element.

From the results of Darwin research (1965) and Ekman (1969) stated that there are facial expression movements that is similar between humans as description of certain emotions. 
They found similarity of kinesics behavior form from the subject of Japanese, Brazilian, Borneo, Papua New Guinea, and US through the faces of the photos taken. Although the culture of the nation is different but gives the same meaning to some photos of facial expressions to express joy or sadness (moodiness). The Conclusion obtained, that kinesics expressing feelings of sad appear that there is movement at left and right corner of human mouth upward ( ). On the contrary, the movement of the two corners of the mouth is pulled downward while showing the feeling of joy and pleasure ( ).

On the contrary, there is a kinesic system that acquires it along with an understanding of the culture and tradition in which a person belongs to a society. This is what causes the tendency of kinesics model between different cultural groups with each other. For Indonesians in general, to say "Goodbye" is expressed with a wave, the hand is lifted up and moved to the right and left. Americans in the same context, their kinesics expressions are different. To convey a farewell greeting, the United States moves forward and moves up and down (like a calling movement). Indonesians express intimacy with friends, when meet, indicated by hugging or patting his back. In contrast, in America (US) is done by rubbing the hair and head of the front (Badu, 2015).

\subsection{Various Kinesic Forms}

The kinesics meaning is closely related to the cultural values developed by a community group. Kinesics research which has been developed by experts generally only focus on one particular culture. While every cultural community is believed it has differences in kinesics model, despite it has also universal the characteristics.

\subsubsection{Smile and Eye Contact}

The research results of Darwin's (1965) and Ekman (1969) as mentioned earlier, that in some cultural areas, there is a common form of expression and meaning to the smile. Someone who is happy in the United States, Brazil, Papua New Guinea, Japan and Indonesia in general will show a smile with an indication that both corners of the mouth are pulled up. Similarly, when he is sad will appear on the opposite expression of the face, ie. the corner of both mouths are moved down. However, each community group can develop various combinations of facial expressions in such a way that the smile can have various meanings only known by the community. In Indonesian culture are known some smile terms, such as smile out of embarrassment, slight smile, and big or sheepish smile. Those are the fact that they differ in context and meaning.

Smile out of embarrassment is a smile without accompanied by a tooth appearance or often called a node smile. The expression of such a smile is usually done for the decency purpose or small talk. When sitting with strangers, as a form of friendly attitude, a person usually shows a smile out of embarrassment, accompanied by a nod as necessary in exchange for permission or ask for a place. Similarly, the habit when in public places, such as in stalls, markets, and so on. Slight smile, as a smile model with a little showing of teeth. This kind of smile, for Indonesian society generally means sympathy, respect, and expression of respect.

The same thing happens when a girl gets praise from a man, as an expression of feelings between shame and joy. Unlike the case with those who engage in conversations with close friends, it will look so familiar with the smiles of a sheepish smile. The more familiar a person besides spiced a sheepish smile is usually also accompanied by verbal expressions and also shake, praise or embrace friendship. Beside that also known smile ridicule. When a group of children play soccer or chase, the winner often throws a smile with the words: "[Hi, hii, ye ora mlebu!]" "(Hi, Hiii..ye...is not enter)" (When the opponent's ball kicks off, does not enter the goal). Similarly, when children play baren (acronyms dissolved), then those who are pursued and feel superior, often tease with a mock smile accompanied by a tantalizing words: "[Ha ..haa, ora kena] "(ha...haa..,is not hit!)". The almost similar thing is a cynical smile. This type of smile is often found in adult groups. A cynical smile is generally an expression of displeasure or envy towards others for reasons of hostility, resentment, competition, and so on. This fact at the same time as a rebuttal to the expression Jer lair iku utusaning batin (What appears is the inner description). It is not rarely for a person to smile even if the inner is cry (prostitute, beggar); on the contrary there is also someone look crying because of happiness expression (bride, when winning the lottery, win the championship, pass the test, and so on).

Although the Indonesian people are known as a friendly and cheap smile (many smile) country, but there is a diversity that applies to every cultural group. For the Javanese and Sundanese smiles is a common and traditionally practiced everyday when talking with friends, meet at the way, even to unfamiliar people as an expression of modesty (Supinah, 2006: 87-89). Therefore, the Javanese and Sundanese considered too much to smile for the Tapanuli people, otherwise the people of Tapanuli (Batak) considered as an expensive smile. 
The term of cheap smile is also attached to the Japanese. The Japanese children smile as a sign of respect when scolded. Similarly, the Japanese will show smile to the mourners when the person he loves dies. This way is done with the intention that the sadness that is being experienced is not felt by others. While Americans are viewed as a very little smile nation (Barre, 1947, Birdwhistell, 1970; Kartomihardjo, 1988).

Eye senses are also involved in direct communication. Communication with this eye language there are several forms, such as staring (looking at the partner), looking down (looking at the ground), and glancing (stealing a glance). In some ways looking at the partner (gazing) while communicating is considered to be describing give attention and earnestness; but not infrequently it was considered as a challenging attitude, as happened in the boxing area to break down the opponent's mental. When someone is advised by the parents, scolded by the leaders for making mistakes, of course the eyesight is not commonly done because impressed to be rude or against. Unlike the case with the attitude of bowed, usually those done by who feel defeated authority (subordinate to the superiors) or show a loyal attitude. A girl when faced a men to give feminine impression also often does bowed attitude. In ancient times when a girl is asked to marry (mated) by her parents she will be silent and ducked and it is interpreted as a positive answer (agree). In other situations, either a man or woman who is mutual but they were not close, usually throws the view by a glance. But this glance also often has a negative meaning, because it is seductive or dishonest behavior (during the test).

\subsubsection{Body Movements}

Although in some cases kinesics means universal, but it is often there are differences in meaning in the same body movement around cultures. The cues of nod and head shake in some cultural communities are defined as agreeable (yes) and reject (no). The research results of La Barre's (Chaika 1982: 57), ethnic groups in Southwest Africa use the opposite cues in interpreting the head shake. They shook their heads to show the word agrees, and nodded when they disagreed. In the hinterland of Kalimantan to show the signs of agreement and rejecting are different. They raised their eyebrows in agreement and frowned when they refused. Different things done by the Abyssinians. They claim to reject (no) by tapping the head to the right shoulder, and the sign agree (yes) by moving the head toward the back with the movement of the forehead upward. The Maori (Australia) to say agree (yes) is shown by the movement of the chin lifted slightly forward with the movement back to the head. But instead of the Sicilians expressed a relatively similar form of movement to the Maori, but to express different intentions, that is to refuse or to disagree

The nod and head shake that refer to the statement agree and disagree would be more general and natural. This is proofed by the same tendency in those who have never learned because of physical limitations. Eibl-Eiblesfeldt (1972) discovers the fact that the blind and deaf mute also use the signal shaking their heads and nod when they reject or approve, even without learning it. That fact reinforces Darwin's thesis (1965) and Ekman (1969) that there are certain body languages created by human innate and instinct (Chaika, 1982: 56-57).

The different ways of pointing directions or as language expressions related to certain cultural aspects are also present in some tribes in Indonesia. The Sundanese, Javanese, Madurese and Balinese use thumbs hand to point in the direction or person. This is done when a person communicates with older people, elders, traditional leaders, officials, or new acquaintances as respect expression. For the Javanese who is hard with politeness, that way is still accompanied by a slightly bent body attitude as a complement to the form of humbling expression. However, it is common to point the direction also used the index finger when the speaking partner is considered lower the social status. And the same intent is expressed with different kinesics by the Tapanuli (Batak). They use lips with their chin slightly raised to indicate the direction or the intended person. And the same thing is done by the Kiowa Indians in America. There are also differences in kinesic behavior in the same tribes of Indian. In America Latin (Panama), the Cuna Indians use lips not only to designate directions but also to create jokes in the context of jokes (Sherzer in Chaika 1982: 57).

When the Japanese greet the other (respectful), the back will be bowed almost 90 degrees. The similar traditions are also carried out by Indonesians, especially in official situations, as is often apparent in a reception or court sights in House of People's Representative (DPR) and People's Consultative Assembly (MPR). A fraction representative, before done the duty gives salutation to the chairman with a bow. The Javanese and Sundanese would do the same thing when they would pass in front of crowds or guests with the body slightly tilted forward. In the Javanese tradition, even such attitudes are part of the measurement of a person's cultural courtesy (the javanesation). The results of Efron study (1972) shows that Jews show respect in a somewhat bent manner and both elbows are attach to the sides of the body. 
The Italians, on the other hand, move their hands freely and confidently. Furthermore, Birdwhistell (1970) in his research found that people who mastered several languages tend to use kinesics in the context of the language they use (Chaika 1982: 57-58).

With regard to the attitude in Javanese tradition, Poedjasoedarma (1988) classifies the Javanese into 3 (three) kinds, namely (1) Jawa, with the meaning understand, (2) ora jawa, means do not understand, and (3) njawani means understanding. Someone is said to be Javanese if in behavior and acts of language can harmonize with norm of custom and Javanese cultural, especially concerning attitude and application of language. Conversely, Javanese is spoken when their behavior and language are incompatible with Javanese cultural norms. The term Njawani applies to people outside the Javanese (non-Javanese) tribe who are able to adapt so that the behavior and language used in communication with the peoples concerned seem to be in harmony with the norms of Javanese tradition.

\subsubsection{Face Expression and Protest Attitude}

The high level of someone education will affect his character and behavior. The more educated and experienced a person will usually be more wise and wise in behaving and attitude. That self-control ability is obtained from learning outcomes in both formal and non-formal education settings. Yet sometimes cultural character is shaped by the environment and is instinctively reflected even though he is well educated. It is usually a kinesic trait that tends to be developed by everyone because of its long-standing cultural influences (Birdwhistell, 1970).

In Indonesia itself is known there are several types and cultural characters that characterize an ethnic. There are cultural groups whose supporters seem to be compassionate (Javanese and Sundanese in general) and there are also certain ethnic groups which exhibit angry behavior (some Tapanuli, Nusa Tenggara and Madura) are captured in facial expression.

The above illustration is a special feature that usually characterizes a particular cultural group and is idiosyncratic. Nevertheless there are common kinesic signals such as look on the characteristics of the sick (pale face, wistful eyes, slow movement, staggering the walk, often complaining, and his voice faltering). On the other hand a healthy person will appear on the kinesic features as follows: glowing eyes, bright and radiant faces, strong breath, stable pulse, firm stance, and a loud voice. While people are happy the kinesics kinesiknya gestures similar to the characteristics of healthy people plus his appearance a lot of smile spread, and sad people approach the characteristics of people who are sick. While angry people appear characterized by certain kinesic features, such as: red face, mouth tightly closed, teeth grinding, hands clenched, and so forth (Kartomihardjo, 1988: 80). Anger attitude that each social group develops is different. The status of relationship between social groups also determines the form of the attitude and nature kinesics. If the opposite party is an equal group, anger can happen reactively and brutally. However, if the conflict is related to a person has power (influential), of course the reaction is different. The fear of physical threats, positions, and certain laws makes the opposition attitude (anger, refusal, criticism) done not openly. The form of criticism is mostly done with more subtle and simplistic. It is not a bit of criticism is done through parodied approach (art of comedy and drama), paintings (posters, drawings, caricatures), literary arts (poetry, short stories, novels), and so on.

In ancient times in the Javanese culture has also been known form of public protests on the king as a authority, known as pepe (sunbathing in field). The people come flocking and sitting on the square (field) in front of the palace by sunbathing do this protest form. They will not relax the action before hearing the decree of the king relating to the problem. The same protests are now being demonstrated by going to the people's representative building, district office or governor, embassy, or visiting the state palace (presidential palace). If it does not get a positive response, not infrequently the people or the demonstrators go on hunger strike until the desire gets attention or granted. Unlike what elite groups do, such sharp and insoluble differences of opinion are often made with hard protests or walkouts. It is as the politicians do in the council building when they are in meeting.

\section{Symbol Language}

As mentioned above that the non-verbal communication system there are 2 kinds, namely body language (kinesick) and symbol language. If kinesics include paralinguistic studies whose meanings involve cultural aspects that are sometimes quite loosely sized so that there is often a misinterpretation, but not so in symbolic language. The term symbol itself means the sign, the form of a statement of language to express ideas expressed in a system of signs or symbols (Moeliono 1990: 840). 
Thus the symbol language here is meant as a system of signs or symbols created by a particular group of people or cultures with the goals and intentions mutually agreed upon by the community. The symbol system as part of the cultural element has much relation with aspects of language and communication, art and literature, religious beliefs, rites, occult sciences, social status, and so forth (Koentjaraningrat 1984: 428). The process of understanding the symbol language is more directed the references and relatively does not cause misinterpretation for all the supporting components.

\subsection{State Simbol}

Each country has certain symbols and can be read as philosophy language for the nation that became the inspiration and spirit of the struggle history of its society in the past. The United States, for example, is famous for its Liberty statue that soars into space as a symbol of freedom and independence. In addition, the image of Liberty statue of depicted by a beautiful woman crowned and her hand carrying a torch symbolized as a goddess of science that will free the nation of the United States from ignorance. Similarly, the flag of the country with the decoration a number of stars illustrates the idea of a unitary state in the form of a federation. It is different with Japan nation, the symbol language of the country is depicted in the form of a rising sun that adorns its national flag. It relates to his belief, which the religion is Sinto who believes the sun as the embodiment of the god worshiped, the God of Amaterasu (the Sun), and so on. Every country has its own symbolic language (Pangastoeti, 2004: 191-193; Badu, 2015: 13-15).

In Indonesia the symbol of the state contains meaning related to the history of long and patriotic struggle for hundreds of years. Before becoming a country as today, the condition of Indonesian nation has ups and downs in the framework of its struggle to free itself from the Dutch colonial (350 years) and Japan (5 years). From the long historical journey that inspires heroism which is manifested in the form of symbolic language of the country as a spirit of common struggle. We recognize the symbol of the country described with an eagle complete with symbols of historical value, such as: the number of wing feathers, tail feathers, neck feathers, which means the monumental event the birth of Republic of Indonesia that is 17 August 1945. Garuda birds as a description of firmness and strength (struggle) with the head turning to the right as a symbol of the sacred struggle in defending the truth against the colonization of the past. Her legs stand firmly by gripping the uniqueness of Bhineka Tunggal Ika's writings (ethnicity and culture) in a unified state. In his chest taped Pancasila shield as a symbol of the spirit that underlies the life of nation and state. Pancasila as the foundation of the state contains 5 symbol language, namely: star (divinity), chain (humanity), banyan tree (unity), head of bison (society), and cotton and rice (justice). Similarly, the red and white on the flag of our country that contains meaning of brave (red) because of right (white). Even the location of color is philosophically positioned, red on top and white below. The position of red and white flag beside refers to the spirit of struggle, also based by religious morals, which means brave because it is based correctly (Kertamukti, 2013: 60-63; Kirom, 2011: 103-105; Turiman, 2014: 129-135).

\subsection{Degree Symbol and Social Status}

Symbol languages are also used in certain institutions to illustrate the high level of rank, such as known in Indonesian Army and Scouting environment. Each of symbol in both institutions has a language meaning that implies someone social status. In the army, either in army, navy, air force, or police there are language symbols that is symbolizing the position of a soldier. Although each institution has its own symbol model, but overall it has the same reference. There are 3 groups of common rank symbols known in the Army, namely (1) enlisted, (2) non-commissioned officers, and (3) officers.

Tamtama that consists of the Warrior level (the red beam symbol on the arm) to the Copral(the symbol is a red crooked beam in the arm). Bintara consists of Sergeant level (yellow bent beam in arm) to the assistant of Lieutenant (symbol of sigma beam on shoulder). While Perwira or officers consisted of 3 groups of levels, namely First Officer (PAMA), Medium Officer (PAMEN), and High Officer (PATI). PAMA groups consist of First Lieutenant (one beam), Second Lieutenant (two beams), and captain (three beams) on the shoulders. PAMEN group consists of Major (the symbol is one jasmine), Lieutenant Colonel (two jasmines), and Colonel (three jasmines) on the shoulders. PATI group the rank consists of Brigadier General (one star), Major General (two stars), Lieutenant General (three stars), and General the symbol is four stars. Similarly, in the scouting are known levels with different symbols, start from Siaga group(mancung or the top of coconut petals), Penggalang (manggar or the flower of coconut by the base is red), Penegak or Enforcer (manggar or the flower of coconut by the base is chocolate), and coach level (Buliali, 2007: 26-28; Farozi, 2014: 163-165). 
In traditional societies there is also classification based on social status. In ancient times, in Javanese society there were two very clear social class, namely kawula alit (aliens, peasants, merchants, and servants) and priyayi (warrior, sentana and raja) classes. Whereas in post-independence era, the Javanese society was divided into 3 class: (1) the group of middle and the rude workers class, (2) merchants class, and (3) employees (Koentjaraningrat, 1984: 229-231).

The other social status descrition in Javanese society is also characterized by prototype of house form. For certain social classes in addition to symbolized in the form of rank (bekel, carik, lurah, penatus, penewu, etc) also marked by other physical symbols, such as joglo house and pendapa and klangenan (the animal likes) like horses or perkutut birds. At the present time, they who are has high social status, beside appears in the form of physical facilities, such as luxury homes, vehicles, and birds klangenan, also in front of the house are displayed beautiful cages with hens stall (Presanti, 2017: 2-4).

In addition to the widely recognized the system of symbol language in Javanese society, social status guidelines for other community groups, such as the Minangkabau tribes(Sumatra) and Minahasa tribes(Sulawesi) are also very clear. For those two tribes, how often holding a traditional party will indicate the level of ability (wealth) and social level (position). At each ceremony will always be accompanied by slaughter of sacrificial animals, especially buffalo. The horn of buffalo head is always displayed in the hall of house or dining room and assembled in stacked. Therefore, the social status of the community is seen from the number of buffalo heads that are displayed. The higher order of buffalo horns that decorate the house, the higher the social status (Fatimah, 2011; Lebang, 2015: 161-163).

In Bali, the high social class society will be marked by the magnitude of Puja buildings and Ngaben ritual ceremonies. For Sundanese people who are predominantly Muslim, the title of "Hajj" is a pride that is included in the scolding system. In addition there is also a social status title that is proud in traditional Sundanese society, such as the Agan title (owner) and Menak (nobility title). Similarly, the symbols language is found in other areas such as Madura, Sasak, Irian, Dayak, and other tribes, although with different symbolic signs and meanings (Sartini, 2017: 105-107; Supinah, 2006: 87-88).

\subsection{Image Symbol and Sound}

There are also many communication systems delivered in the form of images, such as those that apply to traffic signs, instructions about schools, hospitals, restaurants, hotels, etc. On the highway we often encounter traffic signs that guide every rider so as not to impropriety that can harm ourselves and others. On the edge of a busy street there are often signs banned parking and parking. At crossroads there are signs to turn left may continue and are prohibited through this road. In the middle of road are also often found signs may turn, and forbidden to turn, or may turn around except buses and trucks, etc. Still related to the road guide, there are also warning signs the road will climb, the road will decline, be careful slippery road, and so forth. In addition, additional instructions for riders are often found information about the existence of restaurants that can be visited and hotel or lodging.

In scouting organizations also use a fairly philosophical symbol, the Coconut Shoot. It means that a Boy Scout member is a young man who is educated to be a useful human man for the society and his nation as the characteristics of the coconut tree that are beneficial in its entirety. Also in scouting is known other symbol, languages such as in searching the traces and communications with semaphore language (with flags), gathering information, making circles, and form lines. Beside image language Symbol, in scout there is also a sound language symbol known as Morse (with the whistle or sometimes with the light of batteries) familiar in the scouting (Farozi, 2014). In urban communities will be found a symbol of a white flag on the side of road that indicates there is someone died. It also marked the sound of bende (small gong) that is beaten around the village (Sumiyati, 2007).

Still related to the language of sound as a model of message delivery, in commerces side are often found and quite diverse. In Surabaya, the public society can distinguish between the salesman meatballs, tofu tek, or people selling ice, just from the sound language communicated by the seller through the way the sounds were beaten. The seller of tofu tek offers the wares by beating the frying pan, so the voice is not only hard but also big and distinctive. The meatballs seller also different, because something beaten is a bowl of meatballs, so the effect is loud and rather big. Unlike the ice seller, because generally something beaten is a glass, so the sound effect is typically loud and small. 
In rural areas, especially in Javanese society, the sound of kentongan is a familiar medium as communication tool. Kentongan sounds can be used for time markers, fires, deaths, murders, floods, and so on. To mark the beside use kentongan, it also with the bedug sound coming from the place of worship, langgar (worship place smaller than mosques) or mosques. That bedug sound in mosque and langgar (small mosque) besides as praying time marker is also often used in the time of dawn eat in Ramadan. In addition to the sound of the bedug, praying invitation is also marked by the sound of the call to prayer (azan) by the students with the help of speakers (mikropon).

In the world of wayang (puppet exhibition) is also full of variety of symbolic language that describes simplistically the stage of the world, which is nothing but the description of the human world. The wayang performance is led by a dalang (God description) that can determine the direction of the play and the fate played by the characters. Kelir describes as a symbol of mortal world, and the blencong light as the sun that illuminates this world. While the gamelan (instrument) as the description of life rhythm, and the sound of kecrek symbolizes the human heartbeat that the pressure can up and down describes human emotions (Hidajat, 2015: 9-11; Bertens in Wibawa, 2013: 175).

The shapes and colors of puppets also have their own language meaning. The shape of puppet with a distended stomach, gaping mouth symbolizes someone like to eat, and greedy. Upward face symbolizes the nagging and talkative character, while the downcast face has calm in speech. Similarly with the coloring also contains its own meaning. The puppets face in red indicates the irritability such as Baladewa, Arya Setiyaki and the giants. On the contrary, puppets with yellow or white paint colors are usually has temperamental characters as depicted in figures of Arjuna, Nakula, Sadewa, and Puntadewa and the Gods. While the face with black color is usually innocent and honest that depicted in figures of Bima, Gatotkaca, and so forth. There are also puppets that are sometimes dyed blue or dark green and usually symbolize bad and cowardly character. So there are many other symbols depicted in the world of puppet like the shape of eyes, the shape of nose, the shape of mouth, the position of fingers of the hand and it all describes the language and character of puppet characters as prototipe of human character (Mulyono, 1978, Mulyono, 1983, Mertosedana, 1990).

\subsection{Symbol of Fire, Shine, and Color}

In ancient times before people recognized the sophisticated means of communication as they are today, the secret contact of relationships is done by the light of fire. The command of the war leaders to invade and destroy the enemy's position is carried out by the firelight of an arrow being launched into space. It is as a sign (command) "attack" because beside it is still traditional also geographical constraints, because it is generally located in the jungle. In contrast to the present where the means of communication are so modern, such media have been replaced by tools such as phone, Handy Talkie, Hand phone, android, internet, and other sophisticated means.

Different things as communication languages are also conveyed via message with a flame lamp. The everyday scene applies to traffic light symbols at urban crossroads with their own meaning. For example, red (stop), yellow (slow or careful way), and green (allowed to walk). In motor vehicles there is also a sign language through the main lights or lamps send. If it turns on the right side it will turn to the right and vice versa when it turns on the left part of the omen will turn to the left. A similar gesture also applies to taxi drivers driving on the highway. If the inside light is on the sign that the taxi is not passengers or empty, otherwise if run with inside lights in off condition it is a sign of the taxi has passenger. Similarly, if there is a house with a continuous flame, especially a porch light, it indicates empty, being left away (in long time) or uninhabited (Junef, 2014).

Furthermore there is another symbol phenomenon, which is related to Color Language that is often used to express the thoughts and feelings. There are 3 (three) primary colors and 1 neutral color that become the basis of other formation colors, namely yellow, red, blue, and white as a neutral color. The three colors are the original colors contained in this natural environment. The mixture between the basic colors will produce a quite interesting combination of colors (rainbow), which are purple (mixed red and blue), green (blue and yellow), and orange (red and yellow). The image of all the basic colors will produce black (dark). Psychologically the colors can affect the state of someone soul, related to the meaning it represents. Elizabeth Harley states that red represents heat and joy. Therefore red color is often used for the purpose of creating a festive effect and widely used as accessories at parties. The yellow color is the color of the sun. Therefore in addition to the symbol of brightness, the yellow color is also synonymous with majesty and dominates many places as a symbol of grandeur, such as the royal buildings in the past. The blue color is the color of the sky and the vast ocean causing a calm, cool or tranquil effect (Harley in The Liang Gie, 1996: 46-47; Dina, 2015: 277-282). 
In Indonesian culture in general, the colors above represent a certain number of goals. When someone visits a neighbor who dies (mourning), he will wear a dark (black) outfit as an expression of condolence. In hospitals, doctors, nurses, and other medical personnel use white clothing as a "clean" and sterile symbol. Similarly, hospitals are generally painted in white to give a clean impression. Young people who are in love in sending mail always use colored paper or blue motif as an expression of affection and love. Conversely, if a crack or breakup then the red color will dominate the color of paper and writing ink. It describes the feeling of heat, anger, and other upset atmosphere. This color game is also used by painters in expressing ideas and moods on canvas. In addition, the skill of matching color will also influence the enthusiast, marketing, and public recognition of the character of an artist (Adler in The Liang Gie, 1996: 46-48).

\section{Conclusion}

In many ways, the human communication system is so diverse. It is caused by the purpose of communication as a language system. In general context, communications use its verbal form. However, it is not uncommon for a particular purpose to be used in a nonverbal and symbolic form. And the meaning is very dependent on the cultural background of the society philosophical, even if there is a symbol system that becomes a global agreement, for example related to the symbol (sign) of traffic.

(1) Related to a country symbols, such as Garuda Bird (Indonesia), Liberty Statue (United States), Lion Statue (Singapore), Sun (Japan), etc., literally can be read as the philosophical language of nation that became the inspiration and spirit of the struggle history from its society in the past.

(2) The symbols of rank in army especially in Indonesia the references of meaning is more definite and measurable, start from Tamtama (soldiers and corporals), Bintara (sergeant and lieutenant assistance), and perwira (pama, pamen, pati). The first Perwira is 'PAMA' (Second Lieutenant, First Lieutenant, Captain), Intermediate Perwira 'PAMEN' (Major, Lieutenant Colonel, Colonel). The 'PATI' High Perwira consist of Brigadier General (one star), Major General (two stars), Lieutenant General (three stars), and General (four stars). In the context of society tradition there are a number of symbols that describe the social class level. Javanese (house in the model of Joglo, horse, turtle bird); Minangkabau (formation of buffalo horns), Bali (puja and Ngaben building), and others.

(3) An image-shaped symbol as is often found in traffic signs on the road has function as a road user's guide. For example, signs forbids to park, stop, turn left directly, slippery road, narrow road, and so on. In scouting is known semaphore sign (flag code), Morse (whistle). Similarly there are a number of sounds used in traditional societies such like in Javanese, such as the sounds of kentongan (clock) and bende (sign of death).

(4) While the symbol of fire, light, and color, its use is contextual. The symbol of fire in traditional society (formerly) is used as the signal to start the war. In traffic activity, the send lamp has function as a turning mark (right, left, careful), the lights on the taxi (indicate it has content), etc. Related to color symbols, there are intercultural variants, for example in Javanese society, red (brave, angry), white (sacred, true), yellow (greet), black (eternal, sad); but in Tionghoa society the red color has meaning happiness and cheerful. Psychologically those colors can affect the state of someone soul. Therefore, red color is often used to create a festive effect and widely used as accessories at parties.

\section{References}

Arifin, Zaenal E dan S. Amran Tasai. (1987). Cermat Berbahasa Indonesia, Untuk Perguruan Tinggi. Jakarta: Mediyatama Sarana Perkasa.

Badu, Muhammad Nasir. (2015). "Demokrasi dan Amerika Serikat. Democracy and the United States of America".The POLITICS: Jurnal Magister Ilmu Politik Universitas Hasanuddin Volume 1, Number 1, January 2015

Birdwhistell, R.L. (1970). Kinesics and Context. Philadelphia: Univeresity of Pennsylvania Press.

Buliali, Joko Lianto, Faizal Johan, Dian Fetriah. (2007). "Sistem Berbasis Pengetahuan untuk Kenaikan Pangkat Militer TNI AU". JURNAL INFORMATIKA VOL. 8, NO. 1, MEI 2007.

Chaika, Elaine. (1982). Language The Social Mirror. Rowley-London-Tokyo: New Bury House Publishers, Inc.

Darwin, C. (1965). The Expression of Emmotion in Man and Animals. Chicago: University of Chicago Press.

Dina, Rizki Rahma. (2015). "Makna dan Nilai Filosofis Masyarakat Palembang yang Terkandung dalam Bentuk dan Arsitektur Rumah Limas”. Jurnal Ekspresi Seni, Vol. 17, No. 2, November 2015

Efron, D. (1972). Gesture, Race, and Culture. The Hague: Mouton. 
Eibl-Eiblesfeldt. (1972). Similarities and Differencis Between Cultures in Expressive Movements. In S. Weitz. Ed. pp.37-48.

Ekman, O. and W. Frisen. (1976). Measuring Fasial Movement. In S. Weitz . Ed. pp.64-76.

Farozi, Amin dan Umi Fadlillah. (2014). "Buku Saku Gerakan Pramuka Bilingual Berbasis Android". KomuniTi, Vol. VI, No. 2 September 2014.

Fatimah, Siti. (2011). "Kepemimpinan Tradisional Masyarakat Minangkabau pada Masa Pendudukan Jepang". TINGKAP Vol. VII No. 1 Th. 2011.

Fishman, Joshua. A. (1972). The Sociology of Language. Rowley, Massachusetts: Newbury House Publishers.

Furisari, Pipiet. (2016). "Mengenal Karakter Masyarakat Jepang melalui Kinesik Tokoh Utama Dorama Chibi Maruko Chan: Suatu Tinjauan Sosiolinguistik". Dalam Jurnal LITE, Vol. 12, No.1, Maret 2016.

F. Sumiyati, (2007). "Makna Lambang dan Simbol Kentongan dalam Masyarakat Indonesia". https://www.usd.ac.id/lembaga/lppm/f113/Jurnal.

Hall, E. (1959). The Silent Languages. Garden Sity. N.V.: Dobledey.

Hidajat, Robby. (2015). "Aesthetic-Symbolic Presentation of Act of Panji in The Wayang Topeng Malang." Asian Journal of Social Sciences, Art and Humanities, Vol 3, No.2, 2015.

Hymes, D.H. (1974). Foundations of Sociolinguistics: An Etnoghraphic Aphroach. Philadelphia: University of Phennsylvania Press.

Hudson, R.A. (1988). Sociolinguistics. New York: Cambridge University Press.

Junef, Muhar. (2014). "Perilaku Masyarakat Terhadap Opreasi Tilang Bukti Pelanggaran dalam Berlalu Lintas". EJournal WIDYA Yustisia 52 Volume 1 Nomor 1 Juni 2014.

Kartomihardjo, Soeseno. (1988). Bahasa Cermin Kehidupan Masyarakat. Jakarta: Depdikbud.

Kertamukti, Rama. (2013). "Komunikasi Simbol: Peci dan Pancasila". Jurnal Komunikasi PROFETIK Vol. 6, No. 1, April 2013.

Kirom, Syahrul. (2011). "Filsafat Ilmu dan Arah Pengembangan Pancasila: Relevansinya dalam Mengatasi Persoalan Kebangsaan". Jurnal Filsafat Vol.21, Nomor 2, Agustus 2011.

Koentjaraningrat. (1984). Kebudayaan Jawa. Seri Etnografi Indonesia. Jakarta: Penerbit PT. Balai Pustaka.

Kridalaksana, Harimurti. 1983. Kamus Linguistik. Jakarta: Penerbit PT. Gramedia.

La Barre, W. (1947). "The Cultural Basis of Emotions and Gestures". Journal of Personality 16:49-68.

Labov, W. (1972). Sociolinguistic Patternts. Philadelphia: University of Phennsylvania Press and Oxford Blackwell.

Lebang, Yudha Almerio Pratama. (2015). "Analisis Semiotika Simbol Kekuasaan pada Rumah Adat Toraja (Tongkonan Layuk)". eJournal Ilmu Komunikasi, Volume 3, Nomor 4, 2015.

Mertosedana, Amir. (1990). Sejarah Wayang: Asal-Usul, Jenis dan Cirinya. Semarang: Dahara Prize.

Moeliono, Anton M. (1980). "Bahasa Indonesia dan Ragam-Ragamnya", dalam Majalah Pembinaan Bahasa Indonesia Jilid I No. 1, Hal. 15-34. Jakarta: Pusat Pembinaan dan Pengembangan Bahasa.

Moeliono, Anton M. (1990). Kamus Besar Bahasa Indonesia. Departemen Pendidikan dan Kebudayaan Jakarta: Balai Pustaka.

Mulyono, Sri. (1983). Wayang dan Karakter Manusia. Jakarta: Penerbit PT. Gunung Agung.

Pangastoeti, Sri. (2004). "Pergeseran Makna Tennoo sebagai Simbol Negera Jepang”. Humaniora Vol. 16 No. 2, Juni 2004.

Pateda, Mansoer. (1987). Sosiolinguistik. Bandung: Penerbit Angkasa.

Poedjosoedarmo, Soepomo. (1979). Tingkat Tutur Bahasa Jawa. Jakarta: Pusat Pembinaan dan Pengembangan Bahasa, Depdikbud.

Presanti, Desi Ari. (2017). "Etos Priyayi dalam Novel Para Priyayi Karya Umar Kayam”. Alayasastra Vol. 13, No. 1, Mei 2017.

Rejeki, Ninik Sri. (2010). "Perspektif Antropologi dan Teori Komunikasi: Penelusuran Teori-teori Komunikasi dari Disiplin Antropologi”. Jurnal Ilmu Komunikasi Vol. 7, No.1, Juni 2010.

Sartini, Ni Wayan. (2017). "Makna simbolik bahasa ritual pertanian masyarakat Bali". JURNAL KAJIAN BALI Volume 07, Nomor 02, Oktober 2017.

Supinah, Pien. 2006. "Sawer: Komunikasi Simbolik pada Adat Tradisi Suku Sunda dalam Upacara Setelah Perkawinan". Mediator, Vol. 7 No. 1 Juni 2006.

The Liang Gie. (1996). Filsafat Keindahan. Edisi Pertama. Yogyakarta: Pubib.

Turiman. (2014). "Menelusuri Jejak Lambang Negara Republik Indonesia Berdasarkan Analisis Sejarah Hukum". Jurnal Hukum dan Pembangunan Tahun ke-44 No.1 Januari-Maret 2014.

Utaridah, Nanda. (2016). "Representasi Citra Laki-laki Budaya Sunda (Studi Analisis Semiotik Charles Sanders Peirce dalam Sinetron Preman Pensiun”. Jurnal Sosiologi, Vol. 17, No. 2: 135-147.

Weinreich, Uriel. (1953). Language in Contact. New York: Mouton.

Wibawa, Sutrisna. (2013). "Moral Philosofhy in Serat Centhini: Its Contribution for Character Education in Indonesia". ASIAN JOURNAL OF SOCIAL SCIENCES \& HUMANITIES, Vol. 2 No.04 November 2013. 